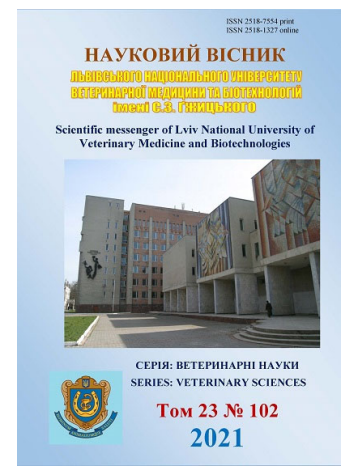

Науковий вісник Дьвівського національного університету ветеринарної медицини та біотехнодогій імені С.3. Гжицького. Серія: Ветеринарні науки

\author{
Scientific Messenger of Lviv National University \\ of Veterinary Medicine and Biotechnologies. \\ Series: Veterinary sciences
}

\title{
Dynamics of hematological parameters in rabbits for osteosubstitution by hydroxyapatite ceramics doped with germanium and in complex with blood coagulation activator
}

\author{
T. P. Todosiuk, M. V. Rublenko, V. M. Vlasenko \\ Bila Tserkva National Agrarian University, Bila Tserkva, Ukraine
}

Article info

Received 29.03.2021

Received in revised form 29.04.2021

Accepted 30.04.2021

Bila Tserkva National Agrarian University, pl. Soborna 8/1, Bila Tserkva, 09117 Ukraine. Tel.: +38-096-757-71-75 E-mail: tatyana.todosyuk@gmail.com
Todosiuk, T. P., Rublenko, M. V., \& Vlasenko, V. M. (2021). Dynamics of hematological parameters in rabbits for osteosubstitution by hydroxyapatite ceramics doped with germanium and in complex with blood coagulation activator. Scientific Messenger of Lviv National University of Veterinary Medicine and Biotechnologies. Series: Veterinary sciences, 23(102), 78-86. doi: $10.32718 /$ nvlvet10212

Bone tissue has powerful regenerative properties, thanks to which, with stable fixation, quite large amounts of skeletal bone damage can be successfully repaired. However, in the case of fragmentary fractures, the use of osteosynthesis methods alone does not always ensure the optimal course of reparative regeneration, as its regenerative potential is lost. Therefore, there is a need to replace post-traumatic bone defects and stimulate reparative osteogenesis. For this purpose, doped or doped with various elements (Ge, $\mathrm{Si}, \mathrm{Zn}, \mathrm{Ag}, \mathrm{Cu}$ ) composite materials. The aim of the study was to investigate the dynamics of hematological parameters in rabbits for osteosubstitution by hydroxyapatite ceramics doped with germanium and in combination with a blood clotting activator. Model defects were formed in the radial diaphysis and femur metaphysis in rabbits with a $3 \mathrm{~mm}$ and $4.2 \mathrm{~mm}$ diameter drill bit, respectively. Anesthesia included acepromazine, thiopenate, and lidocaine infiltration anesthesia. Animals of the first experimental group $(n=12)$ were replaced by defects with granules of hydroxyapatite ceramics doped with germanium (HTGe), the second $(n=12)$ - hydroxyapatite ceramics doped with germanium with blood coagulation activator $(H T G e+a)$, the third $-(n=12)$. hydroxyapatite $\alpha+\beta$ with active $(\alpha+\beta+a)$, and control-granules of undoped ceramics (HT). On day 7, animals of all groups had minor post-traumatic erythrocytopenia and oligochromemia. There was also a gradual increase in the content of leukocytes in the blood with a peak on the 14th day, which in the group HTGe + a lasted until the 30th day. The increase in the number of leukocytes and their peak values occurred within the physiological norm and only approached its upper limit. In most groups there was a pronounced thrombocytosis during the first 14 days with normalization to the 30th day, but in the 2nd experimental group the number of platelets returned to normal only on the 60th day. Changes in most integral hematological indices, which reflect the relationship between blood cell populations, are characteristic of the inflammatory-resorptive phase of reparative osteogenesis. The dynamics of hematological parameters indicates the absence of a pronounced reaction of the body to the implantation of hydroxyapatite composite doped with germanium. The combination of hydroxyapatite ceramics doped with germanium with coagulation activator eliminates post-traumatic oligochromemia and erythrocytopenia and significantly increases the level of hematological integral indices, which indicates a more intensive course of inflammatory-resorptive clinical resorptive aparation phase.

Key words: erythrocytes, integral hematological indices, leukocytes, bone fractures, reparative osteogenesis, thrombocytes.

\section{Динаміка гематологічних показників у кролів за остеозаміщення гідроксиапатитною керамікою, легованою германісм, та в комплексі 3 активатором згортання крові}

Т. П. Тодосюк, М. В. Рубленко, В. М. Власенко 
Кісткова тканина володіє потужними регенеративними властивостями, завдяки яким за стабільної фіксації досить великі за об' смом пошкодження кісток скелету можуть успішно відновлюватися. Однак за осколкових переломів застосування лише методів остеосинтезу не завжди забезпечує оптимальний перебіг репаративної регенерацї, оскільки втрачається ії регенеративний потениіал. У зв'язку з иим виникає необхідність у замішенні посттравматичних кісткових дефектів та стимуляиії репаративного остеогенезу. 3 иією метою використовують нелеговані або леговані різноманітними елементами (Ge, Si, Zn, Ag, Cu) композитні матеріали. Мета роботи - дослідити динаміку в кролів гематологічних показників за остеозаміщення гідроксиапатитною керамікою, легованою германієм, та в комплексі з активатором згортання крові. Формували модельні дефекти у діафізі променевої та метафізі стегнової кісток у кролів свердлом діаметром 3 мм та 4,2 мм відповідно. Анестезіологічне забезпечення включало ацепромазин, тіопенат та інфільтраційну анестезію лідокаӥном. Тваринам першої дослідної групи (n = 12) дефекти заміиували гранулами гідроксиапатитної кераміки, легованої германієм (ГTGе), другої $(n=12)$ - гідроксиапатиною керамікою, легованою германі$\epsilon м з$ активатором згортання крові $(\Gamma T G e+a)$, третьої $(n=12)-$ гідроксиапатитом $\alpha+\beta$ з активатом $(\alpha+\beta+a), a$ контрольної - гранулами нелегованої кераміки (ГT). На 7-у добу у тварин усіх груп спостерігалася незначна посттравматична еритрочитопенія та олігохромемія. Також виявляли поступове збільшення вмісту в крові кількості лейкочитів з піком на 14-у добу, яка в групі ГTGe + а трималася до 30-ї доби. Підвищення кількості лейкочитів та їх пікові значення відбувалися в межах фізіологічної норми $і$ лише наближалися до ї̈ верхньої межі. У більшості груп виявляли виражений тромбоцитоз протягом перших 14-и діб з нормалізаичєю до 30-ї доби, однак у 2-й дослідній групі кількість тромбоцитів прийтла до норми лише на 60-у добу. 3міни більшості інтегральних гематологічних індексів, які відображають співвідномення між популяціями клітин крові, характерні для запальнорезорбтивної фази репаративного остеогенезу. Динаміка гематологічних показників свідчить про відсутність вираженої реакції організму на імплантацію гідроксиапатитного композиту, легованого германієм. За поєднання гідроксиапатитної кераміки, легованої германієм, з активатором згортання крові нівелюється посттравматична олігохромемія і еритроцитопенія та достовірно підвищується рівень гематологічних інтегральних індексів, шуо засвідчує більи інтенсивний перебіг запально-резорбтивної фази репаративного остеогенезу, а це потребує подальшого клініко-експериментального обтрунтування.

Ключові слова: еритроцити, інтегральні гематологічні індекси, лейкоцити, переломи кісток, репаративний остеогенез, тромбоичити.

\section{Вступ}

Репаративний остеогенез як складний і багатокомпонентний, генетично запрограмований біологічний процес, лежить в основі відновлення структурної організації та цілісності кісткової тканини після травми. Ключовими ланцюгами остеорепаративного процесу $\epsilon$ резорбція через запалення пошкодженої тканини, диференціювання клітин, їх проліферація та утворення нової кістки з ії ремоделюванням під дією біомеханічних факторів, формування органічного позаклітинного матриксу, його мінералізація (Diedukh \& Nikolchenko, 2009; Gajko \& Brusko, 2013; Rublenko et al., 2018).

Кісткова тканина володіє потужними регенеративними властивостями, завдяки яким за стабільної фіксації досить великі за об'ємом пошкодження кісток скелету можуть успішно відновлюватися. В ідеалі консолідація перелому приводить до реституції (повної регенерації), що характеризується заміщенням кісткового дефекту тканиною, повністю ідентичною зруйнованій без будь-яких гістоморфологічних відмінностей (Sturmer, 1996; Dmitrijev \& Khomyn, 2017; Dmitrijev, 2018).

Однак з клінічних позицій зрощення перелому досить тривалий багатостадійний процес, на який впливає безліч факторів: інтенсивність та морфофункціональні особливості ділянки травми, характер та ступінь пошкодження кістки і м'яких тканин, наявність посттравматичних розладів периферичного кровопостачання, способи і методи остеосинтезу, післяопераційні інфекційно-запальні ускладнення, наявність вроджених вад кістки або супутньої патології, пов'язаної 3 порушенням структурнофункціонального стану кісткової тканини (остеопоро3).
Найскладнішими серед травм опорно-рухового апарату як у людини, так і у домашніх тварин є осколкові переломи довгих трубчастих кісток, за яких застосування лише методів остеосинтезу не завжди забезпечує оптимальний перебіг репаративної регенерації кісткової тканини, оскільки за наявності багатоплощинної лінії злому та кісткових дефектів втрачається іï регенеративний потенціал насамперед 3 причин втрати остеокондуктивності та порушень локальної гемодинаміки і мікроциркуляції (O'Neill et al., 2018). Кісткові дефекти, які виникають за такого виду переломів, зумовлюють збільшення кількості післяопераційних ускладнень, а надалі можливі розлади статико-динамічної функції травмованої кінцівки і навіть зміни загального стану організму тварини в цілому (Brusko \& Gajko, 2005; Chemerovskyi, 2020).

В зв'язку з цим у низці клінічних випадків для повноцінного відновлення структури і функції кістки виникає необхідність у заміщенні посттравматичних кісткових дефектів та стимуляції репаративного остеогенезу (Trufanov et al., 2014). Хоча “золотим стандартом" у цьому разі вважається аутоостеопластика, проте вона має низку недоліків: унеможливлення заміщення великих за об'ємом дефектів, наявність додаткової хірургічної травми в ділянці відбору аутотрансплантата, втрата нормальної структури та функції “органа-донора”, збільшення часу операції, відсутність повноцінної аутокістки при системному остеопорозі (Chen et al., 2002; Burianov \& Protsenko, 2014; Rublenko et al., 2014). Отже, питання пошуку оптимальних матеріалів для заміщення кісткових дефектів залишається відкритим.

Останнім часом перспективним напрямком у травматології та ортопедії $є$ використання композитних матеріалів, які володіють остеоіндуктивними (здатність стимулювати ріст кісткової тканини в результаті впливу матеріалу на диференціювання мезенхімаль- 
них стовбурових клітин), остеокондуктивними (здатність матеріалу відігравати роль пасивного матриксу для росту нової кістки з подальшою резорбцією матеріалу) та остеоінтеграційними (забезпечення прямого структурно-функціонального зв'язку між імплантом і кісткою) властивостями (Winkler et al., 2018). Своєю чергою композитні матеріали мають відповідати таким вимогам: наявність пористості, що забезпечує проростання нової кісткової тканини; безпечність щодо інфекцій; біосумісність (відсутність токсичної, алергічної, канцерогенної дії), відсутність реакції 3 боку імунної системи організму, доступність та відносно низька вартість.

На сьогодні розроблено і представлено на ринку низку композитних матеріалів вітчизняного і зарубіжного виробництва на основі гідроксиапатиту, $\alpha$ - чи $\beta$-трикальційфосфату, які за своїм хімічним складом та механічними властивостями максимально ідентичні до мінерального компоненту кісткової тканини (Chemerovskyi, 2020).

Заразом вважається (Fujii et al., 1993; Menchikov \& Ignatenko, 2012; Khrabko et al., 2016; Li et al., 2017; Bian et al., 2017), що легування гідроксиапатитних композитів різноманітними елементами 3 метою надання їм нових функцій, які не притаманні нелегованим керамікам, дає можливість отримати кістковопластичний матеріал, який за своїми властивостями наближається до “золотого стандарту” остеозаміщення - аутоостеопластики. Зокрема, до композитних матеріалів додають іони натрію, калію, цинку, алюмінію, кремнію, германію, срібла, міді, магнію, стронцію, що зумовлюють їх остеоіндуктивні властивості.

Спектр зазначених іонів на кістковий метаболізм надзвичайно різноманітний, а тому використання композитної кераміки, легованої іонами мікроелементів, потребує проведення додаткових комплексних експериментальних та клінічних досліджень. Так, германій володіє протипухлинною, анальгезуючою, протизапальною, антиоксидантною, імуномодулюючою, фунгіцидною, противірусною та антимікробною дією, що робить його перспективним за репаративного остеогенезу (Lukevic et al., 1990; Long et al., 1996; Fedoruk et al., 2014; Sakhanda, 2014; Dolaychuk et al., 2015).

Попередньо нами було встановлено (Todosiuk, 2020), що гідроксиапатитна кераміка, легована германієм, за клінічною, рентгено - і макроморфологічною оцінкою проявляє виражені остеокондуктивні та остеоіндуктивні властивості.

Поряд 3 цим залишається дискусійним питання (Gurin et al., 2012) впливу на репаративний остеогенез остеозаміщення $\alpha$ - та $\beta$-трикальційфосфатами та біомолекул фрактурної гематоми (Schell et al., 2017).

3 огляду на те, що кісткова тканина перебуває в тісному зв'язку з кровоносною системою та в динамічній взаємодії з клітинами судин, крові, кісткового мозку - ендотеліоцитами, лейкоцитами, фібробластами, ретикулоцитами, адіпоцитами, клітинами гемопоезу та іншими, за клініко-експериментального обгрунтування нових композитних матеріалів насамперед необхідно визначити реакцію крові.
Мета роботи - дослідити динаміку в кролів гематологічних показників за остеозаміщення гідроксиапатитною керамікою, легованою германієм.

\section{Матеріал і методи досліджень}

Досліди проведені на базі кафедри хірургії та хвороб дрібних домашніх тварин Білоцерківського національного аграрного університету згідно із Законом України "Про захист тварин від жорстокого поводження" від 28.03.2006 р., Правилами Свропейської конвенції захисту хребетних тварин, які використовуються в експериментальних та інших наукових цілях від 13.11.1987 р., та Наказом МОН № 416/20729 від 16 березня 2012 р. "Про затвердження Порядку проведення науковими установами дослідів, експериментів на тваринах". Проєкт виконання представлених досліджень схвалено Етичним комітетом БНАУ протокол № 1 від 23 січня 2019 року.

Роботу виконували на клінічно здорових кролях породи каліфорнійський білий, віком 3 міс., масою тіла 2,5 кг, яких утримували в умовах віварію Білоцерківського НАУ в індивідуальних клітках у приміщенні 3 комбінованим освітленням та примусовою вентиляцією. Прибирання в приміщенні проводилось щоденно. Годівлю забезпечували спеціалізованим комбікормом для кролів (200 г на одну голову за добу). Тварини мали необмежений доступ до води.

Сформували три дослідних $(\mathrm{n}=36)$ та контрольну $(\mathrm{n}=12)$ групи тварин. Анестезіологічне забезпечення за оперативного втручання включало внутрішньом'язове введення $2 \%$ розчину ацепромазину $(0,5-$ 1,0 мг/кг), внутрішньовенне - розчину тіопенату (5-8 мг/кг) та інфільтраційну анестезію по місцю розрізу $0,5 \%$ розчином лідокаїну (3-4 мг/кг).

Оперативний доступ проводили 3 дотриманням правил асептики та антисептики. Після розтину окістя формували модельні дефекти у губчастій (латеральна поверхня дистальної ділянки метафіза стегнової кістки) та компактній (дорсо-латеральна поверхня в ділянці діафіза променевої кістки) кістковій тканині свердлом діаметром 4,2 мм та 3 мм відповідно. Тваринам першої дослідної групи $(\mathrm{n}=12)$ дефекти заміщували гранулами гідроксиапатитної кераміки, легованої германієм (ГТGe), другої $(\mathrm{n}=12)$ - гідроксиапатиною керамікою, легованою германієм 3 активатором $(\Gamma \mathrm{TGe}+\mathrm{a})$, третьої $(\mathrm{n}=12)$ - гідроксиапатитом $\alpha+\beta 3$ активатом $(\alpha+\beta+a)$, а контрольної - гранулами нелегованої кераміки (ГТ). Рани м'яких тканин зашивали вузловими швами із синтетичного шовного матеріалу поліпропілену. Гідроксиапатитна кераміка, $\alpha$ - та $\beta$-трикальційфосфати були синтезовані в лабораторії Інституту проблем матеріалознавства ім. I. М. Францевича НАН України, а ензимний активатор зсідання крові було надано співробітниками відділу структури та функції білка Інституту біохімії ім. О. В. Палладіна НАН України (Komisarenko et al., 2015).

Щоденно у післяопераційний період тваринам усіх груп проводили візуальну оцінку ранового процесу, загальне клінічне і рентгенологічне дослідження. Рани обробляли розчином йоддицерину. Шви знімали 
на 7 добу, оскільки загоєння відбувалося за первинним натягом.

Кров для проведення гематологічних досліджень загально прийнятими методами відбирали із зовнішньої яремної вени перед оперативним втручанням та на 7-у, 14-у, 30-у, 60-у, 90-у добу репаративного остеогенезу. В крові визначали вміст гемоглобіну, кількість еритроцитів, тромбоцитів і лейкоцитів 3 виведенням лейкограми та аналізом якісно-кількісного складу лейкоцитів периферійної крові на підставі обчислення інтегральних гематологічних показників (ІГП), які дозволяють (Klinger \& Jelkmann, 2002; Chemych, 2003; Abd el Rahman et al., 2005; Speranskij et al., 2005; Grin et al., 2006; Elikov, 2011; Chistyakova et al., 2012; Raznatovskaya, 2012) виявити наявність та ступінь ендогенної інтоксикації, типи адаптаційних реакцій організму, перебіг та прогноз захворювання.

При цьому обчислювали такі інтегральні гематологічні індекси:

1) індекс зсуву лейкоцитів (ІЗЛ) - маркер реактивності організму за гострих запальних процесів, що не залежить від загального числа лейкоцитів периферичної крові:

$$
\text { I3Л }=\mathrm{5}+\mathrm{E}+\mathrm{H} / \Omega+\mathrm{M},
$$

де Б - базофіли, Е - еозинофіли, Н - нейтрофіли, Л - лімфоцити, М - моноцити;
2) лейкоцитарний індекс інтоксикації (ЛІІ) - показник процесів тканинної деградації та рівня ендотоксикозу:

$$
Л I I=H / Л+E+M,
$$

де $\mathrm{H}$ - нейтрофіли, Л - лімфоцити, Е - еозинофіли, М - моноцити;

3) ядерний індекс інтоксикації (ЯІІ) - показник, що відповідає за вираженість запального процесу та ефективність лікування:

$$
\text { ЯII }=\mathrm{M}+\mathrm{Ю}+\Pi / \mathrm{C} \text {, }
$$

де $\mathrm{M} \mathrm{-} \mathrm{моноцити,} \mathrm{Ю} \mathrm{-} \mathrm{юні,} \mathrm{П} \mathrm{-} \mathrm{паличкоядерні}$ нейтрофіли, С - сегментоядерні нейтрофіли.

Статистичний аналіз результатів досліджень проводили з використанням MS Excel загальноприйнятими методами варіаційної статистики 3 вирахуванням середнього арифметичного значення (M) та стандартної похибки середнього значення (m). Отримані дані подавали як $\mathrm{M} \pm \mathrm{m}$. Достовірними вважали відмінності між групами $\mathrm{P}<0,05$.

\section{Результати дослідження}

За результатами клініко-рентгенологічних і макроморфологічних досліджень (Todosiuk, 2020) встановлено виражені остеокондуктивні та остеоіндуктивні властивості гідроксиапатитної кераміки, легованої германієм. Загалом у всіх групах встановлена дещо схожа динаміка гематологічних показників (табл. 1).

\begin{tabular}{|c|c|c|c|c|c|}
\hline & Доба & $\begin{array}{c}\text { Еритроцити, Т/л } \\
(4,5-7,5)\end{array}$ & $\begin{array}{c}\text { Лейкоцити, Г/л } \\
(6,5-9,5)\end{array}$ & $\begin{array}{c}\text { Тромбоцити, Г/л } \\
(125-250)\end{array}$ & $\begin{array}{c}\text { Гемоглобін, } \\
(105-125) \\
\end{array}$ \\
\hline & $\begin{array}{c}0 \text { (до операціï), } \\
(\mathrm{n}=48)\end{array}$ & $5,7 \pm 0,06$ & $6,9 \pm 0,09$ & $192 \pm 6,87$ & $117 \pm 1,29$ \\
\hline \multirow{4}{*}{7} & $\Gamma \mathrm{T}(\mathrm{n}=12)$ & $5,1 \pm 0,11^{\star \bullet \bullet}$ & $7,9 \pm 0,38^{\star}$ & $248 \pm 8,91^{+44}$ & $95 \pm 2,60$ \\
\hline & $\Gamma \mathrm{TGe},(\mathrm{I})(\mathrm{n}=12)$ & $5,3 \pm 0,09^{* \bullet}$ & $8,1 \pm 0,33^{* \bullet}$ & $254 \pm 13,05^{* 4+}$ & $100 \pm 2,01$ \\
\hline & $\Gamma \mathrm{TGe}+\mathrm{a},(\mathrm{II})(\mathrm{n}=12)$ & $5,6 \pm 0,09 * *$ & $8,4 \pm 0,22^{+44}$ & $386 \pm 1,43 * * *$ & $115 \pm 3,12 * * *$ \\
\hline & $\alpha \beta+a,($ III $)(n=12)$ & $5,3 \pm 0,07^{+\bullet 4}$ & $7,5 \pm 0,38$ & $261 \pm 7,02$ & $98 \pm 1,69$ \\
\hline \multirow{4}{*}{14} & $\Gamma \mathrm{T}(\mathrm{n}=12)$ & $5,4 \pm 0,09^{\star}$ & $8,8 \pm 0,21^{\bullet \bullet \bullet}$ & $317 \pm 7,29^{*+4}$ & $119 \pm 0,59$ \\
\hline & $\Gamma \mathrm{TGe},(\mathrm{I})(\mathrm{n}=12)$ & $5,5 \pm 0,09$ & $9,6 \pm 0,18^{* * * \bullet \bullet}$ & $339 \pm 8,64^{* 4 *}$ & $121 \pm 1,20$ \\
\hline & $\Gamma \mathrm{TGe}+\mathrm{a},(\mathrm{II})(\mathrm{n}=12)$ & $6,1 \pm 0,12 * * *$ & $9,7 \pm 0,10^{* * * * \bullet \bullet}$ & $423 \pm 9,81 * * *$ & $127 \pm 2,07 * * * \cdots$ \\
\hline & $\alpha \beta+a,($ III $)(n=12)$ & $5,4 \pm 0,08$ & $7,7 \pm 0,20 * * \cdots$ & $350 \pm 5,87 * * \cdots$ & $110 \pm 1,57 * * * *$ \\
\hline \multirow{4}{*}{30} & $\Gamma \mathrm{T}(\mathrm{n}=9)$ & $5,7 \pm 0,07$ & $7,4 \pm 0,12^{\star 4}$ & $185 \pm 4,06$ & $119 \pm 0,98$ \\
\hline & $\Gamma \mathrm{TGe},(\mathrm{I})(\mathrm{n}=9)$ & $5,9 \pm 0,09$ & $7,8 \pm 0,25^{\star \bullet}$ & $196 \pm 7,94$ & $120 \pm 2,84$ \\
\hline & $\Gamma \mathrm{TGe}+\mathrm{a},(\mathrm{II})(\mathrm{n}=9)$ & $7,0 \pm 0,07 * * * \cdots$ & $9,0 \pm 0,20 * * * \cdots \bullet \bullet$ & $353 \pm 7,32 * * *$ & $124 \pm 0,87 * *$ \\
\hline & $\alpha \beta+a,($ III $)(n=9)$ & $5,8 \pm 0,09$ & $7,0 \pm 0,07 * *$ & $198 \pm 1,96^{* *}$ & $110 \pm 0,96^{* * * * * *}$ \\
\hline \multirow{4}{*}{60} & $\Gamma \mathrm{T}(\mathrm{n}=6)$ & $5,7 \pm 0,12$ & $7,0 \pm 0,17$ & $180 \pm 3,08$ & $117 \pm 2,36$ \\
\hline & $\Gamma \mathrm{TGe},(\mathrm{I})(\mathrm{n}=6)$ & $5,8 \pm 0,05$ & $7,0 \pm 0,11$ & $194 \pm 2,59 * *$ & $120 \pm 2,75$ \\
\hline & $\Gamma \mathrm{TGe}+\mathrm{a},(\mathrm{II})(\mathrm{n}=6)$ & $6,8 \pm 0,22 * * * \cdots$ & $7,5 \pm 0,17 *$ & $247 \pm 2,49 * * *$ & $121 \pm 2,61$ \\
\hline & $\alpha \beta+a,($ III $)(n=6)$ & $5,8 \pm 0,08$ & $6,9 \pm 0,11$ & $194 \pm 3,09 * *$ & $110 \pm 1,05^{*}$ \\
\hline \multirow{4}{*}{90} & $\Gamma \mathrm{T}(\mathrm{n}=3)$ & $5,7 \pm 0,09$ & $7,0 \pm 0,15$ & $180 \pm 1,16$ & $118 \pm 1,53$ \\
\hline & $\Gamma \mathrm{TGe},(\mathrm{I})(\mathrm{n}=3)$ & $5,6 \pm 0,03$ & $6,9 \pm 0,15$ & $190 \pm 6,49$ & $120 \pm 1,76$ \\
\hline & $\Gamma \mathrm{TGe}+\mathrm{a},(\mathrm{II})(\mathrm{n}=3)$ & $6,6 \pm 0,37^{*}$ & $6,8 \pm 0,03$ & $213 \pm 4,18 * * *$ & $120 \pm 1,20$ \\
\hline & $\alpha \beta+\mathrm{a},($ III $)(\mathrm{n}=3)$ & $5,7 \pm 0,18$ & $6,9 \pm 0,09$ & $190 \pm 3,93 *$ & $107 \pm 1,53 * * *$ \\
\hline
\end{tabular}

Таблиця 1

Динаміка гематологічних показників у кролів за остеозаміщення різними імплантами

Примітки: 1) значення Р: $\left.*-<0,05 ; 2){ }^{*}-<0,01 ; 3\right) * * *-<0,001$ порівняно 3 контрольною групою; 2) значення Р: • $-<0,05 ;{ }^{\bullet \bullet}-<0,01 ;{ }^{* \bullet} \mathrm{P}<0,001-$ відносно доопераційного рівня

На 7-у добу як у дослідних, так і у контрольних тварин спостерігалася незначна посттравматична еритроцитопенія, яка поступово зникала до 14-ї доби. Також у цей період мала місце олігохромемія з пода- льшою тенденцією до збільшення кількості гемоглобіну в межах фізіологічих величин.

Проте у випадку використання остеозаміщуючого імплантата ГTGe $+\alpha$ олігохромемія була відсутньою. 
Саме в цій групі виявляли найвищі піки підвищення кількості гемоглобіну на 14-у та 30-у добу репаративного остеогенезу. Паралельно до цього протягом всіх термінів дослідження виявляли піки кількості еритроцитів, що мало достовірний характер як порівняно 3 показниками контрольної групи, так і доопераційним рівнем, тимчасом як у решті груп відновлення останнього відбулося на 30-у добу.

Заразом досить суттєві зміни встановлено щодо кількості лейкоцитів і тромбоцитів у периферичній крові. Зокрема, на 7-у добу спостерігалося поступове збільшення вмісту в крові кількості лейкоцитів як у дослідних, так і контрольній групах, хоча і в межах фізіологічних величин. Її пік припадав на 14-у добу i становив у дослідних групах, де використовували кераміку, леговану германієм, у першій $9,6 \pm 0,18$ Г/л та у другій $-9,7 \pm 0,1$ Г/л. Причому в останній він був присутнім і на 30 -у добу репаративного остеогенезу на відміну від решти груп. Загалом підвищення кількості лейкоцитів та їх пікові значення були в межах фізіологічної норми і лише наближалися до іiї верхньої межі.
За аналізу кількості тромбоцитів у більшості груп виявляли виражений тромбоцитоз протягом перших 14-и діб. Так, на 7-у добу реєстрували підвищення вмісту в крові тромбоцитів у першій дослідній групі в $1,3$ раза ( $\mathrm{P}<0,001)$, другій - у 2 рази $(\mathrm{P}<0,001)$, третій - в 1,4 раза $(\mathrm{P}<0,001)$ та в 1,2 раза $(\mathrm{P}<0,001)-\mathrm{y}$ контрольній. Ії̈ пік встановлено на 14-у добу в 1-й, 2-й та 3-й дослідних групах - збільшення рівня тромбоцитів у $1,8,2,2$ та 1,8 раза $(\mathrm{P}<0,001)$ відповідно, а в контрольній - у 1,6 раза порівняно із їх рівнем до операції. Надалі на 30 добу він нормалізувався, однак у 2-й дослідній групі становив ще $353 \pm$ 7,32 Г/л, що в $1,9$ раза (Р $<0,001)$ вище за показник контольної групи та 1,8 раза $(\mathrm{P}<0,001)$ вище доопераційних показників. Лише на 60-у добу кількість тромбоцитів у цій групі прийшла до норми і становили $247 \pm 2,49$ Г/л.

ІЗЛ не залежить від загального числа лейкоцитів крові і здебільшого підвищується при активному запальному процесі та змінах імунологічної реактивності. Його динаміка в групах мала певні особливості (рис. 1).

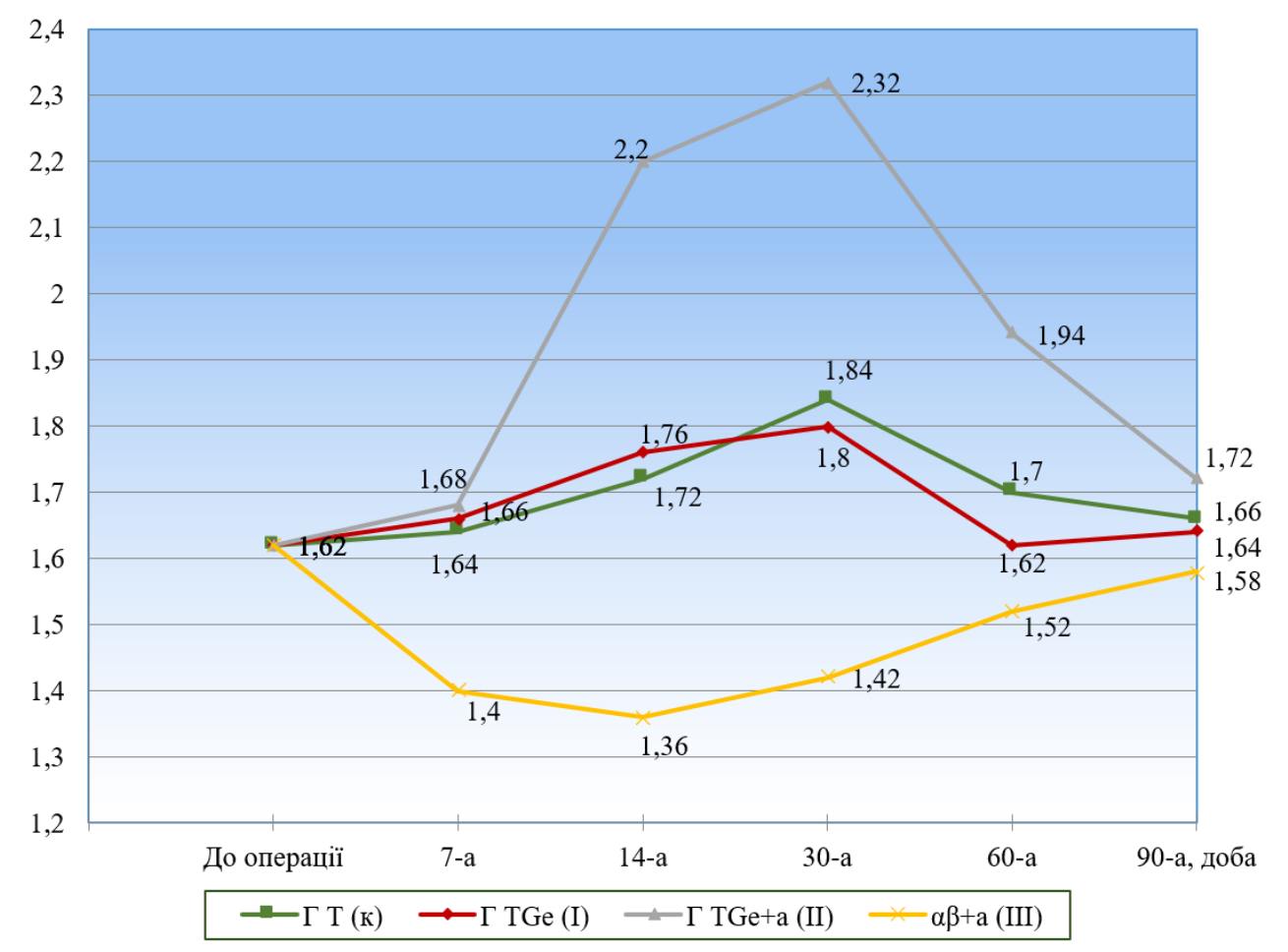

Рис. 1. Динаміка індексу зсуву лейкоцитів крові у кролів за використання різних імплантів

Так, вже на 7-у добу репаративного остеогенезу виявляли тенденцію до зростання ІЗЛ у тварин контрольної, 1-ї та 2-ї дослідних груп, тимчасом як у 3-й він виявився нижчим у 1,2 раза $(\mathrm{P}<0,05)$ порівняно 3 клінічно здоровими кролями.

На 14-у добу ця тенденція набувала достовірного характеру, але у 2-й дослідній групі ІЗЛ (2,2 \pm 0,03 ум. од.) був у 1,4 раза $(\mathrm{P}<0,001)$ більшим, ніж у клінічно здорових тварин. Однак пік показників ІЗЛ спостерігали на 30-у добу, причому в 2-й дослідній групі він був в 1,3 раза $(\mathrm{P}<0,001)$ вищим, ніж у контрольній. Показники цього індекса в усіх групах поступово нормалізувалися до 60-ї доби.

Динаміка лейкоцитарного індексу інтоксикації загалом виявилася подібною до такої ІЗЛ. В подальшому виявляли зростання показника ЛІІ, в 1-й та 2-й дослідних групах на 14 добу він становив у середньому 1,62 та 1,76 ум. од., що в $1,1(\mathrm{P}<0,01)$ та 1,2 $(\mathrm{P}<0,001)$ раза вище за показник контрольної групи (1,52 ум. од.). 


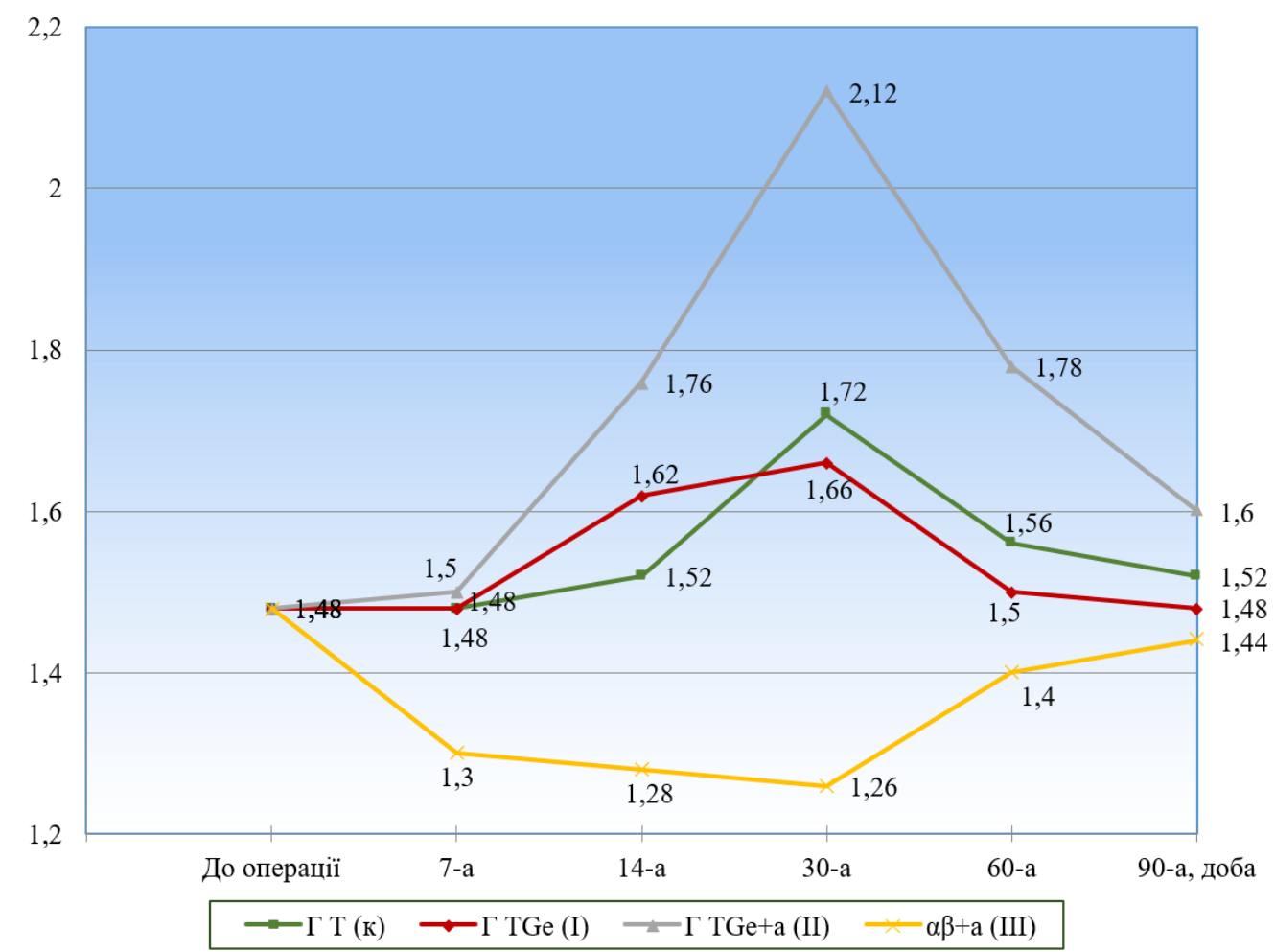

Рис. 2. Динаміка лейкоцитарного індексу інтоксикації за використання різних імплантів

Пік показників ЛІІ спостерігався на 30-у добу в контрольній, 1-й і 2-й групах, що в 1,2 (P < 0,01), 1,1 $(\mathrm{P}<0,01)$ та 1,4 раза $(\mathrm{P}<0,001)$ більше порівняно 3 показниками клінічно здорових тварин. При цьому показник ЛІІ у тварин 2-ї дослідної групи в 1,2 раза ( $<<0,001)$ вищий, а 3-ї - в 1,4 раза $(\mathrm{P}<0,001)$ нижчий порівняно з показниками контрольної групи. В пода- льшому спостерігалася тенденція до нормалізації показників ЛІІ в усіх групах до 60-ї доби репаративного остеогенезу.

Загалом в усіх групах, на відміну від попередніх гематологічних індексів, була схожа динаміка зміни показників ядерного індексу інтоксикації (рис. 3).

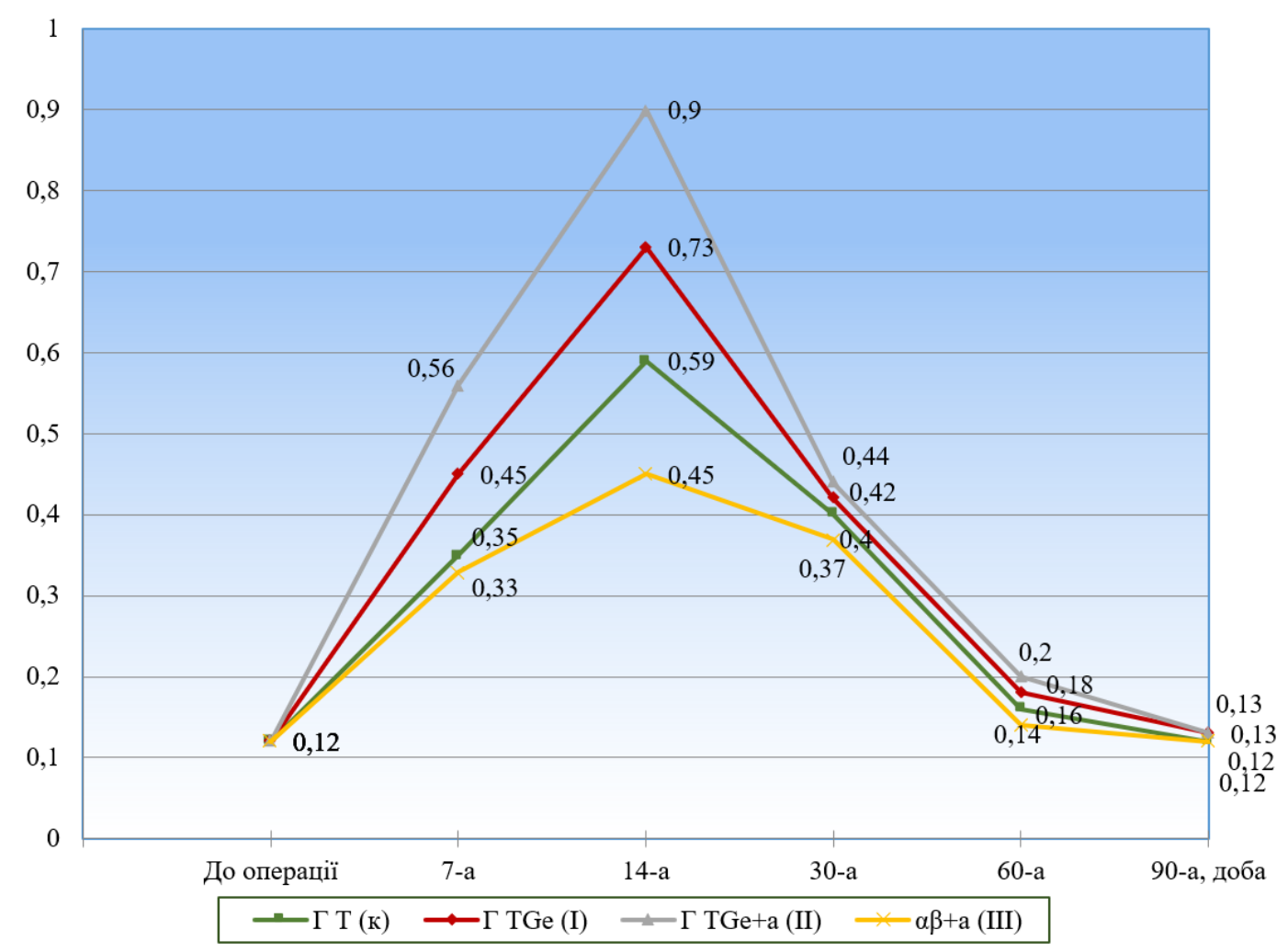

Рис. 3. Динаміка показників ядерного індексу інтоксикації за використання різних імплантів 
Його величина поступово збільшувалася на 7-у добу і свого піку досягла на 14-у добу репаративного остеогенезу. При цьому в 1-й і 2-й дослідних групах вона була в 1,2 та 1,5 раза $(\mathrm{P}<0,001)$ більшою за показник тварин контрольної групи, а в 3 -й - у 1,3 раза нижчою $(\mathrm{P}<0,05)$.

3 30-ї доби в усіх групах ЯІІ починав динамічно зменшуватися, але ще був у 3,1-3,5 раза вищим, ніж у контрольних тварин, проте вірогідної різниці між дослідними і контрольною групами не спостерігалося.

Отже, використання гідроксиапатитних імплантів, легованих германієм, супроводжується реакцією крові, за якої зміни більшості гематологічних показників відбуваються в межах фізіологічної норми, хоча певні особливості має тромбоцитарна реакція і динаміка гематологічних інтегральних індексів, які відображають зміни співвідношення між популяціями клітин крові протягом репаративного остеогенеза.

\section{Обговорення}

Репаративний остеогенез є багатостадійним процесом і здебільшого в його оцінці використовують комплекс заходів, який включає клінікорентгенологічне дослідження, комп'ютерну томографію, лабораторне визначення показників кісткового метаболізму. В експериментальних дослідженнях широко використовуються гістологічні та гістохімічні методи аналізу кісткових регенератів. Виходячи із молекулярно-біологічних закономірностей кісткового метаболізму, ключовою фазою в реалізації всіх стадій репаративного остеогенезу $є$ запально-резорбтивна, яка залежить від багатьох факторів: тип перелому, вид кісткової тканини, спосіб фіксації уламків, наявність інфекційних агентів. Ці фактори в сукупності зумовлюють характер, ступінь, інтенсивність цитокінової реакції, яка, як відомо (Rublenko et al., 2014), зумовлює реакцію системи крові. Найбільш вживаними для iii оцінки є гематологічні показники, які однак досить поверхнево характеризують цю реакцію.

Поряд 3 цим у травматології і ортопедії з метою оптимізації репаративного остеогенезу використовуються різноманітні композитні матеріали для забезпечення остеокондуктивності ділянки перелому. У випадку надання їм остеоіндуктивних властивостей вони потребують оцінки не тільки місцевої, а й загальної реакції організму. Зокрема, як було вказано в ряді робіт (Rublenko et al., 2018; Chemerovskyi, 2020), за використання гідроксиапатиту, легованого кремні$є м$, репаративний остеогенез прискорюється за рахунок скорочення запально-резорбтивної стадії та прискорення проліферативної, головним чином з боку ендоосту з ранньою мінералізацією кісткового регенерату. При цьому динаміка гематологічних показників є типовою для консолідації довгих трубчастих кісток, що свідчить про відсутність вираженої загальної реакції організму на імплантацію гідроксиапатитної кераміки, легованої кремнієм.

Хоча германій, як і кремній, належить до елементів головної підгрупи IV групи періодичної системи елементів і вважається, що він володіє такими ж влас- тивостями, але як показали наші попередні дослідження (Todosiuk, 2020), гідроксиапатит, легований германієм, має більш виражені остеоіндуктивні властивості, що проявляється рентгенологічно і макроморфологічно динамічними явищами остеоінтеграції та раннім ремоделюванням кісткової тканини. Також відомо (Fujii et al., 1993; Menchikov \& Ignatenko, 2012; Khrabko et al., 2016; Li et al., 2017; Bian et al., 2017), що германій володіє досить широким спектром біологічної дії, а його органічні та комплексні сполуки мають протипухлинні, анальгезуючі, протизапальні, антиоксидантні, імуномодулюючі, фунгіцидні, противірусні та антимікробні властивості. Тобто він може бути перспективним не лише в плані остеоіндукції, а й у плані остеозаміщенння у випадку остеомієлітів та неоплазій. Поряд 3 цим існують органічні та неорганічні сполуки, реакція на які також може відрізнятися. В даному дослідженні використовувалася неорганічна сполука германію.

Представлене дослідження насамперед засвідчує, що легування германієм гідроксиапатитної кераміки загалом не змінює динаміки ключових гематологічних показників за репаративного остеогенезу в умовах модельних кісткових дефектів губчастої та компактної кісткової тканини. Хоча прослідковується тенденція до більш вираженого в період 14-ї доби тромбоцитозу та кількості лейкоцитів на рівні верхньої межі фізіологічної норми. Водночас за включення до композиту активатора згортання крові прослідковується певна закономірність, що характеризується відсутністю олігохромемії, достовірним збільшенням кількості еритроцитів і гемоглобіну як свідчення активації гемопоезу, збільшенням рівня тромбоцитів $\mathrm{i}$ гематологічних індексів у період запальнорезорбтивної фази репаративного остеогенезу. Проте у випадку комбінації активатора 3 композитом $\alpha$ - і $\beta$ трикальційфосфатами така закономірність не прослідковується, що, найімовірніше, зумовлене фізикохімічними властивостями останнього.

Таким чином, гідроксиапатитний композит, легований германієм, може бути перспективним імплантаційним матеріалом для заміщення кісткових дефектів і корекції репаративного остеогенезу в тварин.

\section{Висновки}

1. Динаміка гематологічних показників свідчить про відсутність вираженої реакції організму на імплантацію гідроксиапатитного композиту, легованого германієм.

2. За поєднання гідроксиапатитної кераміки, легованої германієм, з активатором згортання крові нівелюється посттравматична олігохромемія і еритроцитопенія та достовірно підвищується рівень гематологічних інтегральних індексів, що засвідчує більш інтенсивний перебіг запально-резорбтивної фази репаративного остеогенезу, а це потребує подальшого клініко-експериментального обгрунтування.

Відомості про конфлікт інтересів. Автори заявляють, що не існує конфлікту інтересів. 


\section{References}

Abd el Rahman A. el Garawany, Othman A. Al Sagair, Ezzat S. el Daly, Kamal A. El Shaikh, Mahmoud H., El Gebaly, Ahmed A., Mousa (2005). Effect of bacterial endotoxin on some metabolites and enzymes in rats serum. Medical Journal of Islamic World Academy of Sciences, 15(2), 65-72. URL: https://jag.journalagent.com/ias/pdfs/IAS_15_2_65_7 2.pdf.

Bian, D., Zhou, W., Den, J., \& Li, Y. (2017). Development of magnesium-based biodegradable metals with dietary trace element germanium as orthopaedic implant applications. Acta Biomaterialia, 64, 421-436. doi: 10.1016/j.actbio.2017.10.004.

Brusko, A. T., \& Gajko, G. V. (2005). Funkcional'naya perestrojka kostej i ee klinicheskoe znachenie. Lugansk, Luganskij gosudarstvennyj medicinskij universitet (in Russian).

Burianov, O. A., \& Protsenko, V. V. (2014). Porivnialna kharakterystyka hidroksyapatytu i biokompozitu materialiv dlia zamishchennia defektu kistky pislia vydalennia pukhlyny. Litopys travmatolohii ta ortopedii, 1-2, 50-56. URL: http://nbuv.gov.ua/ UJRN/Lto_2014_1-2_13 (in Ukrainian).

Chemerovskyi, V. O. (2020). Renthenohrafichna, makromorfolohichna i hematolohichna otsinka hidroksyapatytnoi keramiky $\mathrm{z}$ riznymy fizykokhimichnymy vlastyvostiamy. Naukovyi visnyk veterynarnoi medytsyny, 1, 140-152. doi: 10.33245/ 2310-4902-2020-154-1-140-152 (in Ukrainian).

Chemych, M. D. (2003). Vykorystannia intehratyvnykh pokaznykiv endohennoi intoksykatsii, rozrakhovanykh za dopomohoiu Mytsrosoft Ekhtsel, v otsintsi efektyvnosti terapii hostroho shyhelozu. Visnyk Sumskoho derzhavnoho universytetu. Seriia Medytsyna, 7(53), 84-89 (in Ukrainian).

Chen, H., Hayakawa, D., Emura, S., Ozawa, Y., Okumura, T., \& Shoumura, S. (2002). Effect of low or high dietary calcium on the morphology of therat femur. Nistol. Histopathol., 17(4), 1129-1135. doi: 10.14670/HH17.1129.

Chistyakova, G. N., Gazieva, I. A., \& Remizova, I. I. (2005). Ispol'zovanie integral'nyh gematologicheskih indeksov dlya ocenki stepeni autointoksikacii organizma pri oslozhnyonnoj gestozom beremennosti. Klinicheskaya laboratornaya diagnostika, 12, 34-37 (in Russian).

Diedukh, N. V., \& Nikolchenko, O. A. (2009). Reheneratsiia kistky pry alimentarnomu osteoporozi (eksperymentalne doslidzhennia). Ortopedija, travmatologija i protezirovanie, 2, 34-40. doi: 10.15674/0030-59872009234-40 (in Ukrainian).

Dmitrijev, V. (2018). Features of Dogs Treatment at Fractures of Peripheral Skeleton. Scientific Messenger of LNU of Veterinary Medicine and Biotechnologies. Series: Veterinary Sciences, 20(83), 279-281. doi: 10.15421/nvlvet8355.

Dmitrijev, V., \& Khomyn, N. (2017). Frequency of occurrence and peculiarities of bones fracture of the peripheral skeleton in dogs. Scientific Messenger of
LNU of Veterinary Medicine and Biotechnologies. Series: Veterinary Sciences, 19(82), 180-183. URL: https://nvlvet.com.ua/index.php/journal/article/view/1 361.

Dolaychuk, O. P., Fedoruk, R. S., Kovalchuk, I. I., \& Kropyvka, S. I. (2015). Physiological and biochemical processes in the organisms of rats when feeding them with different amounts of germanium citrate. The Animal Biology, 17(2), 50-56. doi: 10.15407/animbiol17.02.050.

Elikov, A. V. (2011). Zavisimost' pokazatelej eritrocitov u bol'nyh s perelomami kostej goleni v zavisimosti ot sroka. Ortopediya i travmatologiya Rosii, 39, 53-58 (in Russian).

Fedoruk, R. S., Kovalchuk, I. I., Romaniv, L. I., \& Khrabko, M. I. (2014). Vplyv tsytrativ hermaniiu ta selenu na vmist lipidiv $\mathrm{i}$ vazhkykh metaliv $\mathrm{v}$ orhanizmi medonosnykh bdzhil. Biolohiia tvaryn, 16(2), 141-149 (in Ukrainian).

Fujii, A., Kuboyama, N., Yamane, J., Nakao, S., \& Furukawa, Y. (1993). Effect of organic germanium compound (Ge-132) on experimental osteoporosis in rats. General Pharmacology, 24(6), 1527-1532. doi: 10.1016/0306-3623(93)90447-6.

Gajko, G. V., \& Brusko, A. T. (2013). Teoreticheskie aspekty fiziologicheskoj i reparativnoj regeneracii kostej s pozicij sistemnyh predstavlenij. ZHurnal NAMN Ukrainy, 19(4), 471-481 (in Russian).

Grin, V. K., Fistal, E. Y., \& Speransky, I. I. (2006). Integral and other hematologic leukocyte counts as a criterion for assessing the severity of burn disease, its complications and treatment efficacy. Proceedings of the scientific-practical. Conference "Sepsis: the problem of diagnosis, therapy and prevention", 77-78.

Gurin, A. N., Komlev, V. S., Fadeeva, I.V., \& Petrakova, N. V. (2012). Sravnitel'noe issledovanie zameshcheniya defektov kostnoj tkani osteoplasticheskimi materialami na osnove $\alpha$ - i $\beta$-trikal'cijfosfata. Stomatologiya, 6, 16 21 (in Russian).

Khrabko, M., Fedoruk, R., \& Dolaichuk, O. (2016). Fizioloho-biokhimichni protsesy v orhanizmi samyts F0 i samtsiv F1 shchuriv za umov vypoiuvannia yim "nanohermaniiu" tsytratu i tsytratu hermaniiu khimichno syntezovanoho. Visnyk Lvivskoho universytetu. Seriia biolohichna, 73, 226-234 (in Ukrainian).

Klinger, M. H. F., \& Jelkmann, W. (2002). Role of Blood Platelets in Infection and Inflammation. Journal of interferon \& cytokine research, 22, 913-922. doi: 10.1089/10799900260286623.

Komisarenko, S. V., Luhovskoi, E. V., Rublenko, M. V., Andriiets, V. H., Korolova, D. S., Chernyshenko, T. M., Hornytska, O. V., Platonova, T. M., Makohonenko, Ye. M., \& Chernyshenko, V.O. (2015). Sposib oderzhannia autolohichnoho fibrynovoho heliu dlia stymuliatsii reheneratsii kistkovykh i miakykh tkanyn i znyzhennia intensyvnosti zapalnykh protsesiv. Patent na korysnu model №100467. Ukraina. MPK (2015. 01). A61R 19/00 A61R 31/00 (in Ukrainian).

Li, L., Ruan, T., Lyu, Y., \& Wu, B. (2017). Advancesin Effect of Germanium or Germanium Compoundson Animals. Journal of Biosciences and Medicines, 5, 56-73. doi: 10.4236/jbm.2017.57006. 
Long, Q. C., Zeng, G. X., \& Zhao, X. L. (1996). Pharmacocinetics of germanium after po betacarboxyethilgermanium sesquioxide in 24 Chinese volunteers. Zhongguo Yao Li Xue Bao, 17(5), 415418. URL: https://pubmed.ncbi.nlm.nih.gov/9863162.

Lukevic, E. A., Gar, T. K., Ignatovich, L. M., Mironov, V. F. (1990). Biologicheskaya aktivnost' soedinenij germaniya. Riga: Znanie (in Russian).

Menchikov, L. G., \& Ignatenko, M. A. (2012). Biologicheskaya aktivnost' organicheskih soedinenij germaniya (obzor). Himiko-farmacevticheskij zhurnal, 46(11), 3-6 (in Russian).

O’Neill, E., Awale, G., Daneshm, L., Umerah, O., \& Lo, K. W.-H. (2018). The roles of ions on bone regeneration. Drug discovery today, 23(4), 879-890. doi: 10.1016/j.drudis.2018.01.049.

Raznatovskaya, E. N. (2012). Integral'nye indeksy endogennoj intoksikacii u bol'nyh himiorezistentnym tuberkulezom legkih. Aktual'ni pitannya farm. i med. nauki ta praktiki, 2(9), 119-120 (in Russian).

Rublenko, M. V., Chemerovskyi, V. O., Vlasenko, V. M., \& Ulianchych, N. V. (2018). Otsinka osteointehratsiinykh i osteoinduktyvnykh vlastyvostei keramiky, lehovanoi kremniiem, za modelnykh perelomiv stehnovoi kistky u kroliv. Naukovyi visnyk veterynarnoi medytsyny, 2, 44 53. doi: 10.33245/2310-4902-2018-144-2-44-53 (in Ukrainian).

Rublenko, M. V., Semeniak, S. A., \& Ulianchych, N. V. (2014). Dynamika biomarkeriv reparatyvnoho osteohenezu za umov zamishchennia kistkovykh defektiv. Naukovyi visnyk LNUVMBT im. S. Z. Hzhytskoho, 16(3), 287-294. URL: http://nbuv.gov.ua/ UJRN/nvlnu_2014_16_3\%281\%29_40 (in Ukrainian).
Sakhanda, I. V. (2014). Preparaty Hermaniiu ta yikh zastosuvannia $\mathrm{V}$ medytsyni. Ukr. nauk.-med. molodizh. zhurnal, 4(84), 83-86 (in Ukrainian).

Schell, H., Duda, G. N., Peters, A., Tsitsilonis, S., Johnson, K. A., \& Schmidt-Bleek, K. (2017). The haematoma and its role in bone healing. Journal of Experimental Orthopaedics, 4, 5. doi: 10.1186/s40634-017-0079-3.

Speranskij, I. I., Samojlenko, G. E., \& Lobacheva, M. V. (2009). Obshchij analiz krovi - vse li ego vozmozhnosti ischerpany? Integral'nye indeksy intoksikacii kak kriterii ocenki tyazhesti techeniya endogennoj intoksikacii, ee oslozhnenij i effektivnosti provodimogo lecheniya. Zdorov'e Ukrainy, 6(19), 51-57 (in Russian).

Sturmer, K. M. (1996). Pathophysiology disrupted bone healing. Orthopaede, 25(5), 386-393. doi: $10.1007 / \mathrm{s} 001320050039$.

Todosiuk, T. P. (2020). Rentheno- ta makromorfolohichna otsinka reparatyvnoho osteohenezu za implantatsii hidroksyapatytnoho kompozytu, lehovanoho hermaniiem. Naukovyi visnyk BNAU, 2, 183-194 (in Ukrainian).

Trufanov, I. I., Mirenkov K. V., \& Andriyas, I. A. (2014). Kostnaya tkan' - kompozicionnaya osnova opornodvigatel'nogo apparata. Litopys travmatolohii ta ortopedii, 1-2, 26-29 (in Russian).

Winkler, T., Sass, F. A., Duda, G. N., \& Schmidt-Bleek, K. (2018). A review of biomaterials in bone defect healing, remaining shortcomings and future opportunities for bone tissue engineering. Bone Joint Res, 7(3), 232-243. doi: 10.1302/2046-3758.73.BJR2017-0270.R1. 